\title{
PRIPIS K ČLANKU »OŠ PREŽIHOVEGA VORANCA, LJUBLJANA: 50 LET OSEMLETKE IN 110 LET LATINŠČINE POD ISTO STREHO, " KERIA 10, ŠT. 2 (2008): 165-80.
}

Maja 2009, proti koncu prvega šolskega leta, ki poteka v celoti po devetletnem programu, lahko z gotovostjo rečemo, da je novi program za osnovnošolski pouk latinščine v slovenskem merilu veliko razočaranje: štiriletni fakultativni pouk iz časov osemletke je ukinjen, kot izbirnega predmeta $\mathrm{v}$ zadnjem triletju devetletke (torej največ tri leta) pa se latinščine letos uči v vsej državi samo 61 (!) učencev, in sicer 50 na OŠ Prežihovega Voranca in 11 na OŠ Trnovo. Ob prehodu na devetletni program se je pouk latinščine torej ohranil le na dveh ljubljanskih osnovnih šolah, povsod drugod pa zamrl (tu in tam izjemoma obstajajo le še latinske interesne dejavnosti). Če primerjamo to stanje s tistim ob koncu osemletke (npr. leta 2001/02 je bilo v Sloveniji 743 učencev latinščine, in to ne le v Ljubljani, ampak tudi v Mariboru, Murski Soboti in Gornji Radgoni), je povsem očitno, da devetletki ni uspelo ustvariti primernih pogojev za pouk latinščine.

Glavni posledici reforme sta torej izrazito zmanjšanje števila učencev latinščine v Sloveniji ter hkrati okrnjen, za 70 ur skrajšan program za vse, ki se v osnovni šoli odločijo za učenje latinščine. Devetletka je namreč v primerjavi z osemletko, s tem ko je ukinila latinščino v 6. razredu (ne da bi pri tem povečala števila ur latinščine v zadnji triadi), kar za četrtino zmanjšala obseg pouka latinščine. V 110-letni zgodovini naše šolske zgradbe in 50-letni zgodovini OŠ Prežihovega Voranca se je tako septembra 2008 prvič dogodilo, da se učenci pri enajstih letih niso mogli začeti učiti latinščine - velikemu interesu učencev, staršev in šole navkljub. V upanju, da se kaj takšnega ne bo ponovilo in bo pouk obnovljen, se je za leto 2009/10 k pouku latinščine v 6. razredu prijavilo že 39 naših petošolcev, o čemer smo obvestili tudi šolsko ministrstvo.

In kako naprej? Februarja 2009 se je konstituiral Iniciativni odbor za vzpostavitev osnovnošolskih regijskih centrov za pouk latinščine, katerega člani dr. Matjaž Babič, Marjan Gorup, dr. Bogdanka Pirc Marjanovič, Aleksandra Pirkmajer Slokan, dr. Marjeta Šašel Kos in dr. Janja Žmavc si prizadevamo, da bi latinščina v osnovnošolskem izobraževalnem sistemu dobila ustreznejše mesto. Pobudo zanj je dala OŠ Prežihovega Voranca, ki se že več let zavzema za izboljšanje pogojev pouka latinščine in je pred kratkim šolskemu ministrstvu ponovno posredovala tudi svoja predloga programov »Osnovna šola s poudarkom na poučevanju latinščine« (2000) in »Zgodnje učenje latinščine v devetletki« (2007). Naš kratkoročni cilj je takojšnja 
vrnitev latinščine v 6. razred, dolgoročni pa čimprejšnja vzpostavitev humanističnega izobraževalnega programa na osnovnošolskih regijskih centrih po Sloveniji. Smo mnenja, da je ureditev te problematike širšega, nacionalnega pomena in nenazadnje tudi v duhu Evropske skupnosti.

Aleksandra Pirkmajer Slokan 